TITLE:

\title{
Distribution and Characteristics of Slow-Cycling Cells in Rat Vocal Folds(Abstract_要旨)
}

$\operatorname{AUTHOR}(\mathrm{S}):$

Kawai, Yoshitaka

\section{CITATION:}

Kawai, Yoshitaka. Distribution and Characteristics of Slow-Cycling Cells in Rat Vocal Folds. 京都大学, 2017, 博士(医学)

ISSUE DATE:

2017-03-23

URL:

https://doi.org/10.14989/doctor.k20235

\section{RIGHT:}

This is a pre-peer reviewed version of the following article: Distribution and Characteristics of Slow-Cycling Cells in Rat Vocal Folds, which has been published in final form at

http://onlinelibrary.wiley.com/doi/10.1002/lary.25558/abstract;jsession id=324C1E1E551CD4596BCE0E771E41578E.f02t03 


\section{(論文内容の要旨)}

音声は気流が声帯を通過する際の周期的な粘膜振動で生じるが、良好な声帯振動に は声帯粘膜が適度な粘弾性を有していることが必要不可欠である。外傷、炎症、手術 後などに生じる声帯㱂痕では粘弾性の低下から重篤な音声障害をきたすが、有効な治 療法の確立には未だ至っていない。

声帯瘏痕を治療する上で再生治療は有望なアプローチであり、脂肪や骨髄といった 他臓器由来の幹細胞を声帯へ移植する方法は既に有効性が示されている。もう一つの 治療戦略は声帯固有の内因性組織幹細胞を賦活化させての再生効果を期待する方法 である。しかし声帯固有の組織幹細胞は、相異なる解剖学的位置にその存在を示唆す る諸報告はあってもいずれも確定的でない

一般に幹細胞は多分化能以外にも、自己増殖能、細胞周期が長いという特徵が知ら れている。自己増殖能と長い細胞周期という特徵を有した細胞をスローサイクリング 細胞として同定すると、スローサイクリング細胞の中に多分化能を示寸幹細胞が含ま れることが複数の他臟器において既に示されている。

本研究の目的は内因性組織幹細胞の候補と考えられるスローサイクリング細胞を声 帯で同定評価することである。細胞増殖時に DNA 類似物質として細胞に取り込まれ る BrdU を投与後に一定期間を空けると、分裂周期の緩徐な細胞に BrdU が残存する。 さらに Ki-67 染色で陽性の細胞は細胞増殖能を有すると判断できるため、BrdU と Ki-67 が共陽性となる細胞をスローサイクリング細胞として検出した。

まず、BrdU 投与終了後の適正な待機期間を検討するためラット腹腔内に BrdU を $50 \mathrm{mg} / \mathrm{kg} / \mathrm{day}$ で 7 日間連続投与し、投与 1 日後、5 日後、10 日後、15日後に評価し た。結果、投与 1 日後と 5 日後では声帯粘膜上皮、粘膜固有層、黄斑に BrdU 残留が 認められたが、10 日後、15 日後ではほぼ声帯粘膜上皮に BrdU 残留が集中していた。 声帯を主に構成する細胞の細胞周期から計算すると理論上 150-200 時間で BrdU が 全て希釈流出することからも、BrdU 投与終了 10 日後時点をスローサイクリング細胞 の同定時期として設定した。

10 日後時点での声帯スローサイクリング細胞の分布評価を行ったところ、声帯全層 に存在が認められるもののその殆どが粘膜上皮基底層に局在していた。さらにスロー サイクリング細胞の表面マーカーを評価したところ、声帯粘膜上皮基底層に分布する スローサイクリング細胞の一部で E-cadherin や CK5 といった上皮マーカー陰性の細 胞が存在し、間葉系マーカーの Vimentin や内皮細胞マーカーの CD31 陽性細胞が相 対的に多く認められるなど周辺の粘膜上皮細胞とは異なる性状を示した。また、粘膜 固有層内に僅かに分布するスローサイクリング細胞は周囲の細胞と比較し線維芽細 胞マーカーである S100A4 陽性率が低かった。

次に BrdU 投与後待機期間中に声帯損傷を行ったところ、損傷後の時間に応じて経 時的なスローサイクリング細胞の減少が認められた。
本研究により声帯粘膜におけるスローサイクリング細胞は声帯粘膜上皮基底層に主 に分布することを確認した。また声帯のスローサイクリング細胞には周囲と異なる特 徵を有寸る細胞が含まれることを確認した。声帯損傷時にスローサイクリング細胞が 減少し創傷治瘉に動員されたと考えられた。今後、声帯組織幹細胞の同定のためス口 一サイクリング細胞の多分化能に関する検証が必要である。

\section{(論文審査の結果の要旨)}

外傷、炎症、手術後等に生じる声帯瘢痕は重篤な音声障害をきたし治療法は未確立 である。声帯固有の組織幹細胞を賦活化する再生治療は有望だが、その存在すら確実 とは言えない。他臟器において自己増殖能と長い細胞周期という特徵を有するスロー サイクリング細胞を同定するとその中に多分化能を示す幹細胞が含まれることが示さ れている。本研究の目的は声帯のスローサイクリング細胞を同定評価することである。 BrdU を投与し一定期間後に観察すると緩徐な細胞周期の細胞に BrdU が残存する。 BrdU と自己増殖能を示寸 Ki-67 が共陽性になる細胞をスローサイクリング細胞とし た。条件検討を行い BrdU 投与後待機期間は 10 日とした。スローサイクリング細胞は 声帯全層に認めるもその殆じが粘膜上皮基底層に分布していた。粘膜上皮基底層に女 る同細胞は上皮マーカー陰性（E-cadherin、CK5）、間葉系マーカー陽性（Vimentin）、 内皮細胞マーカー陽性（CD31）の細胞を一部含み、粘膜固有層にある場合も S100A4 陽性率が周囲より低いなど周辺細胞と異なる性状を示した。声帯損傷後は経時的にス ローサイクリング細胞が減少し、活発に分裂して創傷治癒に寄与した可能性が示され た。

以上の研究は声帯に存在する組織幹細胞の解明に貢献し、新たな声帯瘢痕治療戦略の 端緒を開く上で寄与するところが多い。

したがって、本論文は博士（医学）の学位論文として価值あるものと認める。

なお、本学位授与申請者は、平成 29 年 1 月 23 日実施の論文内容とそれに関連した 試問を受け、合格と認められたものである。 